Pil Hansen

Christopher House

\title{
HAY W WYKONANIU HOUSE'A OCENA ZASAD KREACJI I WYMAGAŃ POZNAWCZYCH SYSTEMÓW PERFORMATYWNYCH ${ }^{1}$
}

W jaki sposób możemy lepiej rozumieć, przekazywać i rearanżować dzieła taneczne, które nie są oparte na powtarzalnych schematach, ale systemowo generowane na scenie? Systemy performatywne najlepiej opisać jako półzamkniętą formę natychmiastowej kompozycji w tańcu i teatrze: dramaturgię rozpoznanych zadań, zasad i źródeł, w ramach których artyści wchodzą w interakcje na scenie. Te interakcje nie są ani predeterminowane, ani przypadkowe - samoorganizują się one wokół zmieniających się elementów, które z upływem czasu prowokują pewne rodzaje zachowań. Zazwyczaj obejmują także wyzwania poznawcze, angażujące i przyspieszające proces uczenia się odmiennych sposobów percepcji podczas spektaklu. Ucieleśnione ślady pamięciowe powstają dzięki treningowi $\mathrm{w}$ ramach systemu, a nie przestrzennym, czasowym czy relacyjnym znakom, znanym z bardziej konwencjonalnych podejść. Te niezmiernie wymagające ćwiczenia i kompozycje przekazywane są dalej zazwyczaj podczas warsztatów z choreografem lub reżyserem, którzy zainicjowali ich powstanie, bądź z performerami, którzy byli zaangażowani w ich rozwój. Ta personalna i ucieleśniona forma przekazu ma swoje zalety, gdyż skraca czas treningu oraz zwiększa tempo rozwoju umiejętności na kolejnych etapach procesu uczenia się, nie sięga jednak daleko poprzez dyscypliny, kultury i czas.

Aby pójść dalej, musimy zrozumieć, wyartykułować i uzewnętrznić zasady kluczowe w procesach tworzenia widowiska przez poszczególne systemy. Szukałam podejścia, które pomogłoby mi zidentyfikować i przeanalizować takie zasady. Podejście, metoda czy technologia analizy i dokumentacji wpływają na spektakl, który badają, i zmieniają go. Nasz sposób powinien minimalizować ten wpływ, dopasowując się do elementów różnych systemów performatywnych i kalibrując się podczas każdego użycia. Równie ważne jest, aby jego efekt był kreatywnie użyteczny i produktywny. Produktywność i użyteczność wyprzedzają to, co André Lepecki nazwał „wolą archiwizacji”, rozumianą jako „zdolność do zidenty- 
fikowania w historycznych pracach niewyczerpanych jeszcze pól kreatywności” (Lepecki 2010, s. 31) oraz otwartość na to, do czego może prowadzić ich ponowne ucieleśnienie. Takie spojrzenie odzwierciedla założenia nowej, postdramatycznej dramaturgii, a mianowicie skupienie się nie na tym, czym jest spektakl i jego znaczenie, ale na tym, w jaki sposób działa i czego dokonuje. Przedstawiona na początku tej pracy krótka koncepcja systemów performatywnych opiera się na pochodzącej z kognitywistyki teorii układów dynamicznych (DST - Dynamical Systems Theory), spełniającej omawiane tutaj warunki.

Dla porównania konwencjonalne systemy notacji, takie jak kinetografia Labana, system Banesha i DanceWriting (notacja Valerie Sutton), zapisywały głównie aspekty ruchu. Nagrania wideo oraz zaawansowane technologie charakteryzują się podobnymi ograniczeniami. Nie da się ponownie wykonać systemu performatywnego, odtwarzając zapisane ruchy. Dopiero poprzez ponowne zastosowanie zasad kreacji spektakl może być (od)tworzony. W ciągu ostatniej dekady notacja i partyturowanie [notation and scoring] tańca ewoluowały poza metody konwencjonalne. Maaike Bleeker zwraca uwagę na to, że zaawansowane technologicznie archiwa mają za zadanie uruchomić aktywne myślenie o ruchu, a nie tylko go odwzorować (Bleeker 2010, s. 3). Ambitnym przykładem takiego archiwum jest strona internetowa Scotta deLahunty - Motion Bank. Zachęca ona widzów, aby udali się na samodzielną wyprawę badawczą, poruszając się pomiędzy wywiadami z artystami opatrzonymi przypisami, nagraniami wideo, prezentacjami wzorów ruchu w pracy z podłogą i graficznymi animacjami reakcji na dzieła ikonicznych choreografów, w tym Debory Hay (Motion Bank). Jest to zasób, który umożliwia myślenie o ruchu i poprzez ruch, ale nie próbuje narzucić kompleksowego zestawu zasad jego tworzenia.

We współpracy z działającą w Wielkiej Brytanii uczoną Freyą Vass-Rhee oraz szeregiem choreografów zastosowałam teorię układów dynamicznych do opisu systemów performatywnych tańca współczesnego. To pozwoliło nam przeanalizować, w jaki sposób systemy tworzą spektakl i dzieło, oraz zapisać je za pomocą łatwych do przystosowania, komplementarnych metod. Moim pierwszym studium przypadku był system „rzutowania w przyszłość” [futuring memory] wykorzystywany przez Ame Henderson i Public Recordings w relay (Toronto 2010) (zob. Hansen 2015a). Drugie studium to „dotykowy” system Karen Kaeji z Kaeja d'Dance, Crave (Toronto 2013/2017) (zob. Hansen, Kaeja, Henderson 2014). Trzecie studium to solo I'll Crane for You Debory Hay w wykonaniu Christophera House'a. W czwartym studium przypadku Vass-Rhee analizuje Whole in the Head Williama Forsythe'a (Frankfurt 2010). Kontynuując temat możliwości poznawczych - tworzenie systemów performatywnych obejmuje artystyczne dociekania na temat ludzkiej pamięci i percepcji, a ich częstym celem jest wypracowanie rozpoznawalnej obecności w performansie. Artyści, ograniczeni przez restrykcyjne zasady, nieustannie pracują nad „nieosiągalnymi zadaniami”, a ich wysiłki przyciągają widownię. Wymagają one równoległej aktywacji specyficznych i często 
konkurujących ze sobą rodzajów uwagi, co potencjalnie rozszerza pojemność pamięci roboczej artystów i zwiększa ich elastyczność poznawczą - konieczną, aby reagować twórczo. Jednocześnie, wykonywane zadania wymagają od nich nieustannego omijania (czyli blokowania [inhibit]), zmiany przeznaczenia lub testowania pamięci długotrwałej, by pokazać światu coś nowego. Innymi słowy, ucząc się performować w ramach konkretnych systemów, tancerze prawdopodobnie rozwijają nienormatywne sposoby przetwarzania poznawczego, które są tak samo istotne w procesie tworzenia spektaklu jak zadania, zasady i materiały źródłowe definiujące granice systemów. Wraz z Robertem J. Oxobym (ekonomistą behawioralnym), Viną Goghari i Emmą Climie (psycholożkami eksperymentalnymi) zaczęłam sprawdzać te hipotezy $\mathrm{w}$ pilotażowych badaniach eksperymentalnych na Uniwersytecie Calgary (zob. Hansen, Oxoby 2017). W poniższej pracy wspólnie z House'em omawiamy wyzwanie, jakim jest opis I'll Crane for You (zarówno pod względem zasad kreacji, jak i procesu uczenia się) za pomocą teorii układów dynamicznych. Przedstawiona propozycja powstała w wyniku dialogu dwóch perspektyw, które graficznie odzwierciedlają kursywa (reprezentuje doświadczenia artysty-adaptatora) oraz czcionka prosta (przedstawia analizę dramaturga-naukowca).

\section{Zastosowanie teorii systemów dynamicznych (DST)}

Aby przetestować granice opartej na DST koncepcji powstawania spektaklu, zajęłam się solowym spektaklem choreografki Debory Hay. Koncepcja powstała bowiem na podstawie konkretnych przypadków, które dużo łatwiej pogodzić $\mathrm{z}$ teorią systemów dynamicznych.

W przypadku systemu „rzutowania w przyszłość” Henderson zadaniem tancerzy było osiągnięcie unisono (ruchu symultanicznego) bez zrzekania się indywidualności. Strategia polegała na tym, aby świadomie sformułować hipotezę co do miejsca, w którym inni tancerze będą w następnym momencie, i wyjść im na spotkanie. Naśladowanie było zabronione. Zamiast tego tancerze nieustannie modyfikowali swoje hipotezy na podstawie postrzeganych różnic pomiędzy ich ruchem a ruchem partnerów. Jednocześnie artyści mieli za zadanie przywoływać wspomnienia przeszłych choreografii za każdym razem, gdy skłaniało ich do tego skojarzenie fizyczne. Te przywołane fragmenty zapamiętanej choreografii były następnie „rzutowane w przyszłość” przez pozostałych tancerzy.

Zastosowałam wersję teorii systemów dynamicznych proponowaną przez Thelen i Smith (1994). DST analizuje, w jaki sposób interakcje pomiędzy zmiennymi generują zachowania w systemach złożonych prowadzące raczej do lokalnej samoorganizacji niż do równowagi przewidywanej przez drugą zasadę termodynamiki. Pierwszym krokiem zastosowania DST jest zidentyfikowanie parametrów $i$ zmiennych, które w najbardziej znaczący sposób wpływają na interakcje w ra- 
mach danego systemu. W relay parametrami były zadania i zasady „rzutowania w przyszłość”, natomiast zmiennymi: nawyki i wyszkolenie tancerzy. Następny krok to zidentyfikowanie zewnętrznego źródła energii, które wprawia interakcje w ruch i podtrzymuje ich kierunek. W relay źródłem energii były wspomnienia choreografii z przeszłości. Po zidentyfikowaniu wspomnianych elementów system jest analizowany pod kątem parametrów porządku, stanów atraktora, zmiennych, które zakłócają równowagę i wytwarzają przejścia i zmiany fazowe. Krótko mówiąc, parametr porządku przyciąga pewną formę zachowania wewnątrz systemu. To zachowanie trwa, dopóki inna zmienna nie stanie się konkurencyjnym parametrem porządku zakłócającym równowagę systemu. Wtedy system przechodzi w nową fazę, przyciągając inną formę zachowania wokół tego parametru, dopóki nie pojawi się nowe wyzwanie.

Etapy procesu uczenia się oraz ilość przywołanych wspomnień stanowiły główne parametry „rzutowania w przyszłość”. Ucząc się nawyków ruchowych partnerów i przywołując wspomnienia, artyści zaczęli rozwijać wspólne dla wszystkich leksykony ruchu [movement vocabulary]. Za każdym razem, gdy do systemu wprowadzano nowe wspomnienia, leksykony rozpadały się i trzeba było rozwijać nowe. $Z$ upływem czasu artyści stali się mniej zależni od informacji wizualnych i byli w stanie formułować trafniejsze hipotezy na podstawie bodźców słuchowych oraz tego, czego nauczyli się, przewidując w ramach spektaklu. W efekcie udało im się osiągnąć momenty ruchu symultanicznego.

Istnieją trzy wstępne warunki konieczne, aby połączyć metodę DST i relay: 1) system jest pół-zamknięty, dzięki czemu jestem w stanie zidentyfikować jego zmienne i śledzić zmiany; 2) jest otwarty na nowe wspomnienia oraz artystów, którzy umożliwiają jego dalszą generatywność, ale zarówno artyści, jak i wspomnienia są możliwe do zidentyfikowania w momencie dołączenia do systemu; 3) przechodzą przez różne etapy procesu uczenia się, w tym kilka zmian faz, w przeciągu półtorej godziny, co stanowi obserwowalny okres.

Wracając na krótko do kwestii tego, w jaki sposób takie spojrzenie wpływa na system: na dalsze tło schodzą ideologiczne motywacje, które są odpowiedzialne za powstanie „rzutowania w przyszłość” i mogłyby stanowić interpretacyjne ramy jego politycznych implikacji. Na pierwszy plan wychodzą natomiast zasady generowania interakcji, tworzone przez nie wzorce oraz zmiany w orientacji percepcyjnej i możliwościach poznawczych. DST kieruje naszą uwagę na to, co było źródłem danych działań, a nie na to, dlaczego je podjęliśmy, lub na sposoby ich interpretacji czy konceptualnej lub ideologicznej syntezy. Taka zmiana podejścia nie musi być jednak permanentna. Żadne epistemologiczne kryteria nie zabraniają nam zmieniać punktu widzenia tak często, jak wymagają tego cele dramaturgiczne - po prostu nie jesteśmy w stanie oglądać spektaklu z dwóch perspektyw jednocześnie. Dodatkowo identyfikowanie parametrów porządku przyciąga uwagę do tych aspektów spektaklu, które podlegają samoregulacji, a odciąga od tych, które jej nie podlegają. I chociaż takie podejście tworzy zdecydowanie bardziej 
złożoną reprezentację samoorganizującej się dynamiki niż np. analiza wzorców ruchowych, jego celem nie jest oderwanie ruchu od powtarzania, tak istotnego w pracy Hay i Henderson.

\section{Wymagania nienormatywnego przetwarzania poznawczego}

Sposób, w jaki zasady kreacji wpływają na artystę, jest kluczowy do zrozumienia jego performatywności - czyli tego, jak pracuje. W związku z tym należy przyjrzeć się wymaganiom poznawczym wynikającym z zastosowania tych zasad. Proces uczenia się wspomnianych wyżej wspomnień i reakcji partnerów pozwala artyście korzystać ze świeżo wydobytych zasobów pamięci długotrwałej w celu przewidzenia następnego momentu. Ten postrzegalny rozwój umiejętności jest wspierany przez procesy poznawcze, które są najprawdopodobniej nienormatywnie wzmacniane i uzewnętrzniane (uświadamiane) przez wymagania systemu.

„Tancerz rzutujący w przyszłość” wykonuje zadania, przestrzegając zasad danego systemu performatywnego. Jego procesy percepcyjne zależą od tego, w jaki sposób wykorzysta on aktualną informację do sformułowania hipotezy na temat miejsca, w którym performerzy spotkają się w następnym momencie spektaklu. Według Hansena i Oxoby'ego takie ukierunkowanie jest kinestetyczne i wielomodalne, „gdyż włącza czucie głębokie i układ motoryczny, widzenie peryferyjne oraz kanał słuchowy. Zarazem skupienie uwagi, którego wymaga trening oraz jednoczesne podtrzymywanie tych kanałów percepcji, wymaga kontroli wykonawczej w pamięci roboczej” (Hansen, Oxoby 2017, s. 79-80). Pamięć roboczą opisuje się zwykle jako system tymczasowego przechowywania i przetwarzania informacji postrzeganej w danym momencie lub wydobytej z pamięci długotrwałej. Procesy pamięci roboczej obejmują funkcje wykonawcze takie jak podtrzymywanie uwagi i mentalne manipulowanie informacją oraz wygaszanie dystraktorów (Lawyer-Savage, Goghari 2016; Miyake, Shah 1999). W tym przypadku rozwijanie hipotezy przez tancerza wymaga od niego wykonawczego rozwiązywania problemów. Co więcej:

Ucząc się wzorów reakcji partnerów, performerzy kierują uwagę na wiele elementów jednocześnie, przerzucają uwagę pomiędzy „rzutowaniem w przyszłość” a wydobywaniem wspomnień, a tym samym ćwiczą elastyczność poznawczą i generatywność (Lövden i in., 2010). Zasady (jak np. „nie naśladuj”, „nie prowadź”, „nie kopiuj”) przeczą umiejętnościom i nawykom zakodowanym w ukrytej proceduralnej i epizodycznej pamięci długotrwałej. Matryca poznawcza wzbogaca się w związku z tym o funkcję wykonawczą wygaszania. Innymi słowy, podczas gdy normatywne przetwarzanie polega głównie na postrzeganiu i nieświadomym reagowaniu, celem systemów performatywnych jest zahamowanie pamięci długotrwałej przy jednoczesnym poszerzaniu zakresu uwagi artysty do aktualnych bodźców sen- 
sorycznych oraz zwiększeniu jego możliwości przetwarzania bodźców przy użyciu funkcji wykonawczych (np. pojemności pamięci roboczej, elastyczności poznawczej, generatywności) (Hansen, Oxoby 2017 s. 79-80).

Cechy takie jak poszerzona, multisensoryczna uwaga, podzielność uwagi, hamowanie pamięci długotrwałej czy elastyczność poznawcza nie są cechami przystosowawczymi, szczególnie gdy powtarzalna i niezawodna skuteczność zależy od wybiórczej uwagi i nieświadomych nawyków. Pozwalają one natomiast tancerzom zwiększyć zakres uwagi, wzmocnić ich umiejętności reagowania w nietuzinkowy sposób oraz dłużej utrzymywać wysiłek, który przyciąga publiczność. Opisane efekty powinny zostać dodane do ugruntowanego przekonania, że zarówno systemy performatywne, jak i ustrukturyzowana improwizacja zwiększają aktualność spektaklu, zastępując mniej lub bardziej zautomatyzowane podczas prób interakcje rzeczywistymi reakcjami.

\section{Hay w wykonaniu House'a: testowanie granic}

Solowe adaptacje na podstawie solowej aranżacji Hay (1998-2012) składają się z czterech elementów, które dopiero połączone w całość tworzą spektakl. Pierwszym z nich jest to, co Hay nazywa „treningiem” (Hay 2013; Drobnick 2006, s. 44). Polega on na zapoznaniu się z szeregiem kwestii i wartości wynikających z jej buddyjskiej koncepcji ciała, artystycznych dociekań oraz pracy choreograficznej. Realizuje się go podczas warsztatów z Hay, pracując nad jedną z jej partytur. Następny element to pisemna partytura solo, opisująca kombinację metaforycznych, paradoksalnych i narzuconych działań, w tym pytań „a co by było gdyby?" i uwag odnoszących się do treningu. Trzeci komponent to sam rearanżujący artysta, zazwyczaj znany choreograf, który zaopatruje wyzwania systemu w specyficzną historię tradycji tańca i umiejętność kompozycji. Ostatnim elementem jest zgoda na serię warunków: artysta musi podjąć się ćwiczenia całej partytury, bez przerw, pięć dni w tygodniu przez trzy miesiące, zanim spektakl będzie mógł być przedstawiony publiczności. Celem takiego rozwiązania jest przyjęcie perspektywy początkującego wobec partytury każdego dnia (a nie powtarzanie jej sekcjami). Na pierwszy rzut oka wydaje się, że ten przypadek jest zbyt otwarty na informacje sensoryczne i interpretacje partytury (energię zewnętrzną), aby poddać go analizie opartej na teorii systemów dynamicznych DST.

\section{Praktyka}

Praktyka Hay jest niezwykle dobrze udokumentowana m.in. w partyturach Motion Bank i publikacjach Bojany Bauer (2015), Jima Drobnicka (2006), Susan Foster (2000) i samej Hay (2000). Jej terminologia jest jednakowoż nieokreślona: „Słuchaj mojego ciała jako nauczyciela” (House, 2015) oraz: 
A co jeśli za pomocą tańca wprowadzam w życie moją relację z ciałem jednocześnie w relacji do przestrzeni, w której tańczę, w relacji do każdego upływającego momentu, w relacji do mojej publiczności?

A co jeśli głębia tego pytania leży na jego powierzchni? (Hay 2007, s. 2).

Tego typu treningowe pytania i uwagi są wplecione w partytury Hay. Mają być dla tancerza źródłem dostępu do cielesnego sprzężenia zwrotnego. Działają na zasadzie nieustannego kierowania uwagi percepcyjnej ku relacji pomiędzy ciałem a otoczeniem, przy jednoczesnej rezygnacji z planowania, modelowania i nawyków ruchu. Hay pyta: „A co jeśli mój sposób postrzegania podczas tańca jest środkiem, za pomocą którego ruch powstaje bez świadomego poszukiwania?”.

Hay prosi swoich wykonawców o "samoregulująca transcendencję choreograficznego ciata" wierzac, że taniec oparty na zgromadzonym doświadczeniu jest zbyt ograniczajacy. Opisuje tę transcendencję jako "stratę o katastroficznych proporcjach" (House 2006-7, s. 5). W zamian za to proponuje nowy sposób patrzenia na spektakl.

Jej narzędzia treningowe sa zaprojektowane tak, aby artysta utrzymywat się $w$ "tu i teraz", zwracal uwage na reakcje i poruszat się, aby nie dać się rozproszyć myślom. Niezbędne jest do tego wyrafinowane pole widzenia i wiele narzędzi Hay; kładzie ona nacisk wtaśnie na czynność „widzenia”. Tak samo jak ciało/umyst nie może przywiazać się do jednej koncepcji, uczucia czy obiektu lub zatrzymać się na nich, tak pole widzenia musi się wiecznie przesuwać. Przesuwanie obejmuje zmianę ogniskowej, kąta perspektywy, spłaszczanie hierarchii identyfikacji i zanikanie tradycyjnej granicy artysta-publiczność.

W swojej solowej rezydencji w 2009 roku Hay zaczęta mówić o tym, jak istotne jest odwracanie głowy - „rusz głowa, do cholery!”. Konfrontujac się z nowym polem informacyjnym, ciało jest natychmiast odświeżone i dostymulowane. Patrzenie staje się niczym karmienie ciała, a ruch bierze się wtaśnie z tego aktu sensorycznego, a nie z inwencji, rozwoju czy historii choreograficznej artysty.

Prawdopodobnie trening redukuje normalny sposób filtrowania bodźców sensorycznych przez artystę i - tak jak „rzutowanie w przyszłość” - może poszerzyć jego funkcje pamięci roboczej poprzez zmianę form uwagi. Hay chce, aby tancerz przestał polegać na nieświadomej pamięci długotrwałej, i dlatego przestrzega go przed wyuczonymi reakcjami. Zapobiega planowaniu i zachęca do hamowania zautomatyzawanej tendencji do tworzenia serii ruchów, prosząc tancerzy o „wyjęcie sekwencji z ich sekwencji” (Hay 2007, s. 2). Jej wybór formy solowej w dużej mierze uniemożliwia nieświadome kopiowanie ruchów charakterystyczne dla tańca rozrywkowego. Tancerze relacjonują, że to podejście zwiększa ilość przetwarzanych bodźców sensorycznych w niemożliwym do utrzymania stopniu. Ujmując to w terminologii teorii systemów dynamicznych DST: tancerz jest niezwykle otwarty na nowe źródła energii, które mogą zapobiegać samoorganizacji systemu i generowaniu performatywnemu. 


\section{Adaptujący performer}

Kiedy Christopher House, dyrektor artystyczny Teatru Tańca w Toronto, rozpoczynał trening, Hay zwracała mu uwagę na jego nawyki i prosiła, żeby się ich pozbyl. By nie tylko trenował pracę wbrew swoim umiejętnościom i przyzwyczajeniom, ale także oduczał się ich. W ciągu niemal dziesięciu lat House przyjął i dostosował sposób pracy Hay. Wraca do praktyki krótkiej formy, jaką jest „ciało jako nauczyciel” podczas prób, aby powstrzymać się przed planowaniem lub osiągnąć wymagany podwyższony poziom somatycznie zorientowanej percepcji. Innymi słowy, blokowanie i uwaga sensoryczna nie są podtrzymywane nieustannie, ale reaktywowane za każdym razem, gdy normatywne i zautomatyzowane formy procesu poznawczego zaczynają kształtować reakcje performera w trakcie spektaklu.

Podczas performansu skupiam się głównie na otwarciu mego ciała na bodźce pochodzace $z$ danych $w$ laboratorium - powstrzymuję się od wykonania "dobrego pomystu", który wymagałby przygotowania, aby odkryć coś świeżego i nowego. Staram się odkrywać każdy ruch w tym samym momencie, w którym odkrywa go widownia.

House skutecznie redukuje przeładowanie sensoryczne wynikające ze sposobu pracy Hay. Rozwija strategie, w tym obrazowanie i specyficzne dzielenie pola uwagi, które sprawiają, że zadanie nieustannego czytania relacji cielesnych staje się bardziej konkretne. Może na przykład jednocześnie obrazować i postrzegać odczucia pochodzące z części ciała, na której w danym momencie jest skupiona jego uwaga sensoryczna. Tego typu strategie powalają mu skoncentrować percepcję na jednej w pełni ucieleśnionej relacji w danej chwili, a nie na wszystkich naraz. Poza ograniczeniem przeładowania sensorycznego stosowane przez House’a strategie generują komunikaty, które z kolei mogą uruchomić sprzężenie zwrotne - efekt, do którego artysta dąży, reagując jednocześnie w czasowych ramach pamięci roboczej. W wykonaniu House’a trening zostaje przekształcony w zestaw warunków i strategicznych zadań, które można zidentyfikować i badać jako parametry systemu dynamicznego.

House ma tendencję do tworzenia płynnych sekwencji wynikających z jego wyszkolenia, a z których raz po raz rezygnuje w ramach treningu Hay. Ta tendencja staje się zmienną systemu. Zmiennymi są także zarówno jego silne strony, z których nie rezygnuje (np. jak sam to opisuje: „zainteresowanie i miłość do synchronizacji”), jak i ograniczenia (jako takie House traktuje m.in. znaczniki przestrzenne) (Hansen 2015b).

Jako performer standardowo bawię się z czasem. To stąd czerpię największa przyjemność $i$ to tu jestem najbardziej pewny siebie. To, jak postrzegam przestrzeń, wymaga statej uwagi, a wiele $z$ moich najbardziej uzytecznych narzędzi pochodzi $z$ przestrzennych pytań Hay - np. „Co by było, gdyby wszystkie komórki mojego ciała naraz byty w stanie postrzegać przestrzeń jako całość, zmieniającą się wraz z moim ruchem?" (House 2006-7, s. 3). Powracając do świadomości przestrzennej, przypominam sobie, aby postrzegać wtasne ciato jako „barometr przestrzeni”. 
Zmienne w postaci mocnych i słabych stron House’a da się zarejestrować, jak również można $\mathrm{z}$ nich zrezygnować, bawić się z nimi lub rozwiązać je za pomocą strategii treningowych. W związku z tym można je zidentyfikować oraz obserwować ich efekty. W rzeczy samej, House zaprasza widownię do pewnego rodzaju obserwacji.

Zachęcam do zobaczenia mojego catego ciała jako przedmiotu rozważań.

Na potrzeby analizy DST uznałam zapis partytury Hay za zewnętrzne źródło energii. Wszystkie inne komponenty spektaklu pozostają niezmienne, podczas gdy partytura dostarcza nowej energii, która wprawia system w ruch.

Tak samo jak w przypadku treningu, dzięki House'owi zapis partytury I'll Crane for You Hay staje się bardziej dostępny. Szczegółowe kodowanie i analiza nagrań z czterech spektakli ze stycznia 2015 roku uwidoczniły przejścia (a nie zmiany) pomiędzy niewielkimi „subakcjami” w każdej z partii. Wystąpiły pewne różnice $\mathrm{w}$ zakresie orientacji przestrzennej i prędkości ruchu, natomiast jego jakość, zaangażowane części ciała oraz synchronizacja pozostały podobne.

Czytając ponownie zapis partytury Hay przez pryzmat wspomnianych subakcji, odkryto, że House sprecyzował partie, które Hay pozostawiła otwarte na interpretację, natomiast zaadaptował i otworzył te, które podyktowała choreografka. W ten sposób zostały ograniczone zmiany następujące pomiędzy metaforycznymi a narzuconymi partiami, a partytura i pośrednictwo tancerza zyskały na ciągłości.

Na niektóre partie łatwo było House'owi reagować w obrębie treningu Hay, inne natomiast wymagały od niego budowania specjalnych strategii radzenia sobie z nimi.

Niczym otwierający się wachlarz, przestrzeń sceniczna ożywa wraz z jego wejściem - samotna krzywa ścieżka.

Kładąc nacisk na niewyraźność rozpościerającej się przed nim ścieżki, wykonuje niewyraźny taniec $\mathrm{w}$ niewyraźnej przestrzeni, poszerzając zajmowaną przestrzeń sceniczną. Niewyraźność jest zmysłowym uczuciem w obszarze zmysłowo postrzeganej przestrzeni, która obejmuje publiczność... nie chce być uznany za odmiennego i zakłada, że publiczność czuje to samo (Hay 2007, s. 2).

Otwarcie I'll Crane for You było dla mnie niesamowitym wyzwaniem. W żadnej innej części nie kusiło mnie aż tak, aby przygotować coś imponującego, a wiedziałem, że byłby to śmiercionośny wybór. Znalazłem inspirację $w$ stwierdzeniu, którego Anne Bogart użyła w swojej książe A Director Prepares: „Dla malarza przemoc to pierwsze pociagnięcie pędzla po ptótnie" (2001, s. 54). Zaczątem traktować wejście ("Niczym otwierajacy się wachlarz”) jako skok w przestrzeń bez użycia spadochronu, gwaltowny gest, który wplywa na wszystko, co po nim następuje. Wykonując to wejście, wchodzę w intensywna relację zarówno z laboratorium (przestrzenia, w której tańczę), jak i z publicznościa, która spotykam wtedy po raz 
pierwszy. To dla mnie porywające uczucie - poruszać się szybko i zdecydowanie, ale bez pośpiechu, i nagle, bez widocznego przejścia, znaleźć się wewnątrz niewyraźnego tańca.

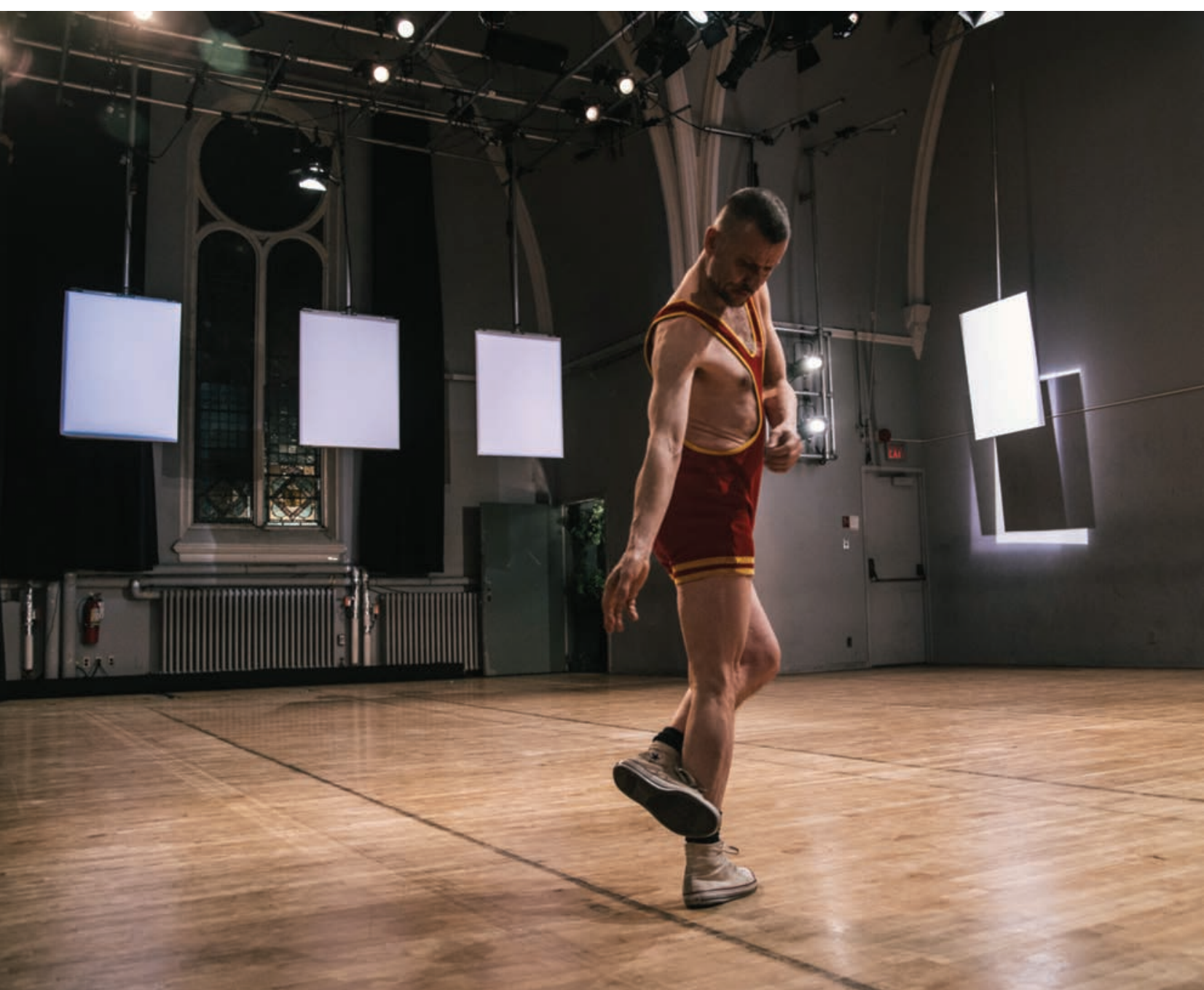

Zdj. 1. House wykonuje Niewyraźność [Blurry]

Zdjęcie: Alejando Santiago (Hansen, House 2015, s. 69).

Łatwiej było mi przyswoić niewyraźny taniec-być może dlatego, że proponuje on potaczenie czasu i przestrzeni. Cieszę się, że wymaga on niesamowitej specyficzności i różnicowania - bycia zarazem wszędzie i nigdzie. Podczas spektaklu chcę wplywać na to, jak publiczność postrzega przestrzeń, za pomoca subtelnych i nieprzewidywal- 
nych zmian wyrazu, kreując szlaki ruchu przy użyciu przeróżnych powierzchni mojego ciała i zmieniając położenie części ciała względem siebie nawzajem (na przykład ramion względem nóg, kąta pomiędzy przedramieniem a ramieniem, dtugości kroku $i$ kąta, pod którym moja stopa uderza w podłogę). Moim celem jest, aby publiczność nigdy nie byta w stanie ani przewidzieć, ani przypomnieć sobie mojej ścieżki - równocześnie odstonić i wymazać.

Zaczyna on od performowania scenerii [landscape], orientacyjnie proponując publiczności - i sobie - różne kąty, pod którymi można obserwować mniej więcej tę samą scenerię. Nie kreuje scenerii, lecz zauważa ją, gdziekolwiek by nie był.

Wykonuje dwa kroki naprzód, jeden wstecz - metafora życia (Hay 2007, s. 4).

House szybko wygenerował reakcje na zdarzenie scenerii [landscape], ale - biorąc pod uwagę wskazówki Hay - wykonanie ich wymagało już podjęcia pewnego ryzyka. 
Kiedy rozważałem koncepcję scenerii, przyszło mi do głowy ćwiczenie, którego nauczyta mnie Chrysa Parkinson. Jest to ćwiczenie na świadomość ciała $w$ relacji do powierzchni podłogi i niezliczonych stopni geometrii pomieszczenia. Sceneria stała się dla mnie bardzo zmysłowym zdarzeniem przestrzennym: zauważałem, że wyłaniajace się proste, płaszczyzny i krzywe oscylowaty pomiędzy pierwszym planem a ttem. Po siedmiu latach zanurzenia w treningu Hay otworzyłem moje ciało na nowa świadomość doznań.

Moje poczynania, wszystkie $z$ nich na podłodze, obejmowaty poziom kontroli, który można by nazwać wirtuozeria, i zastanawiałem się, czy nie za mocno naciskam na trening. Ucieszytem sie, gdy tuz przed premiera, kiedy trenowatem $w$ Austin, Hay zachęciła mnie, abym pogłębit swoje podejście. Zakładam, że znalazłem sposób na bycie wirtuozem, pozostając jednocześnie „przedmiotem rozważañ”.

House studiował scenerię, jednocześnie kreując i rozpatrując ją w relacji do pomieszczenia. „Dwa kroki naprzód, jeden wstecz” było większym wyzwaniem, jako że w kółko starał się o to, co zostało podyktowane. Mając w pamięci, że Hay nazwała to kontynuacją scenerii, House znalazł rozwiązanie: zintegrował ten proces z ostatnią częścią badania scenerii i w ten sposób zamienił kroki taneczne w etapy obserwacji scenerii.

Podczas pracy nad zdarzeniem partyturowym „Obrót obrót obrót obrót obrót obrót obrót... Obrót obrót obrót obrót obrót obrót obrót...” (Hay 2007, s. 4) nie wiedziatem, co zrobić. Wszystko, czego próbowatem, odczuwatem jako przekombinowane i/lub oczywiste. Zaczątem więc poruszać się, unikając obrotów i zwracać uwagę na to, kiedy ruch objawiat się jako obrót. Po raz kolejny przejście od wykonywania ruchu do skupienia na bodźcach percepcyjnych pozwoliło House'owi znaleźć rozwiązanie uwalniające $\mathrm{w}$ przeciwnym razie nakazowe zdarzenie partyturowe, bez utraty specyfiki.

$\mathrm{W}$ rozwijanie tych strategii zaangażowany był proces rozwiązywania problemów, który domknął się podczas prób i przygotowań do spektaklu. Tak przygotowany House performował przed publicznością. Dzięki temu, że dostępne mu były opracowane wcześniej strategie, wymagania poznawcze takie jak rozwiązywanie problemów, uwaga sensoryczna, przerzucanie uwagi oraz blokowanie zostały ograniczone. Pozostała co prawda oparta na elastyczności poznawczej presja, aby generować nowe reakcje, jednak była realizowana $w$ warunkach łatwiejszych do wykonania zadań, zasad i źródeł. Krzywa procesu uczenia się, zarówno artystycznego, jak i poznawczego, jest zatem niezbędna, aby rearanżować solową aranżację Hay.

$\mathrm{Z}$ drugiej strony, kiedy zbuduje się już tak użyteczne strategie, podtrzymanie ich - a jednocześnie niepowtarzanie konkretnych ruchów czy efektów powstałych podczas prób - pozostaje wyzwaniem. Wracając do teorii systemów dynamicznych DST: narzucone źródło energii zewnętrznej szybko zostałoby wyczerpane, podczas gdy metaforyczne źródło energii rozszczelniłoby system, nie pozwalając mu na samoorganizację. Adaptacja Houséa radzi sobie z tymi dy- 
namicznymi ograniczeniami, tworząc niewyczerpalne, określone, ale nie sztywne źródło energii, które inicjuje generowanie tańca, utrzymuje półzamknięty system i nadaje mu kierunek.

\section{Umowa}

Nie przeanalizowaliśmy jeszcze największego wyzwania, przed jakim stajemy, chcąc zrozumieć funkcjonowanie aranżacji I'll Crane for You oraz to, jak można opisać ją w ramach teorii systemów dynamicznych DST. Czwarty element projektu - zgoda na trzy miesiące trenowania partytury - znacząco wydłuża czas życia systemu. To samo dotyczy treningu poprzedzającego dzieło. Stawiam czoła nie dziewięćdziesięciu minutom „rzutowania w przyszłość”, ale miesiącom czy nawet latom pracy.

Niektóre ze skrótów House’a stanowią odpowiedź na problem wydłużonego procesu uczenia się. House prowadzi warsztaty, dzięki którym mogłam zaobserwować, jak daleko potrafią zajść początkujący w ciągu jednego dnia. Komplementarnym rozwiązaniem jest założenie społeczności trenerskiej, gdzie artyści praktykujący adaptacje solowe pomagają nowym członkom podczas początkowych etapów treningu, wykonując partyturę. Ważne jest, aby zapisywać partyturę we wszystkich fazach trzymiesięcznego treningu, a skrócenie tych faz w większym stopniu wplynie na proces uczenia się artystów.

Po raz pierwszy House nauczył się I'll Crane for You w 2007 roku, w trakcie jedenastodniowej rezydencji, podczas której trenowała go Hay. Solo i wymagania Hay stanowily wyjściową partyturę w spektaklu zespołowym, który stworzyła ona później w tym samym roku dla Teatru Tańca Toronto (Up until Now). W roku 2014, gdy po raz pierwszy powrócił do swojej partytury, House usiłował wydobyć i wykonać sekwencję partii w poprawnej kolejności i bez przerw. Było to niezmiernie trudne zadanie, ponieważ techniki zapamiętywania tancerzy zazwyczaj opierają się na zestawach kroków lub wyznacznikach przestrzennych, których brakuje w partyturach House'a. Następnie pracował nad ciągłością - unikaniem przeskakiwania od partii do partii. Synchronizacja, tempo oraz latwiej dostępne, otwarte elementy powrócily jako pierwsze. Za nimi wróciły ślady porzuconych nawyków i zabawa umiejętnościami. Dopiero później House wydobył trudniejsze partie, co wymagało od niego niezliczonych prób, budowania strategii, wielokrotnego powracania do zapisu partytury i pytań treningowych, aby „dokopać się do języka” (House 2015, s. 5).

Zadaniem wykonawcy w jednej z partii jest opowiedzenie „spontanicznej historii”, zarazem „prostej i kosmicznej” (Hay 2007, s. 3). Po trzech miesiącach treningu House opowiedział ponad sześćdziesiąt historii, których doświadczał jako „załamujących się jedna $\mathrm{w}$ drugą poprzez niespodziewanie wyłaniające się i rozwiązujące tematy”. Stanowiąc improwizowane narzędzie dramaturgiczne, ta 
„zabawa językowa dostarczała sprzężenia zwrotnego zarówno z tym, co widownia już widziała, jak i z tym, co dopiero miała zobaczyć” (Hansen 2015c). Jako widz dostrzegam jego intuicję mojego doświadczenia, a jako dramaturg - zdaję sobie sprawę z tego, jak czasochłonne jest wzbudzenie i stworzenie ram narracyjnych dla tak dużej liczby improwizowanych opowieści. Uważam to za dobry przykład tego, w jaki sposób z upływem czasu generowana jest aktywnie ewoluująca pamięć treningu (w przeciwieństwie do formalnych ćwiczeń tanecznych). Skrócenie czasu trwania treningu mogłoby spowodować spadek ilości splecionych ze sobą śladów przeszłych reakcji, a co za tym idzie - uboższy repertuar reakcji podczas spektaklu.

Kiedy już opracował strategie i utrwalił specyficzny dla partytury trening, House osiągną podmiotowość. Dokonywane przez niego wybory, poszerzając warunki Hay, stały się zobowiązujące, a zasady jego rozwiązań przeniosły się na inne aspekty dzieła, czyniąc z niego Hay w wykonaniu House'a, ale też House'a w adaptacji Hay.

Tuż przed fazą, w której House osiągnął podmiotowość, Hay zrecenzowała jego pracę, pozytywnie odnosząc się do jego wyborów (w przeciwieństwie do zalecenia powrotu do antycypacji jej intencji). Być może to właśnie w tym poparciu tkwi klucz do rozwiązania problemu rozciągnięcia w czasie.

\section{Uczenie się, przeniesienie i dystans}

Porównując solowe aranżacje na stronie Motion Bank z adaptacjami House’a, zauważa się pewną wspólną jakość ruchu - estetykę łączącą niezależnych wykonawców, którzy przez dłuższy czas trenowali rutyny Hay. Wydaje się, że z upływem lat jej proces oduczania prowadzi do powstawania nowych nawyków, których nie da się zinterpretować wyłącznie jako braku stylistyki i ruchu planowanego. Nie jest to również proces tożsamy z załamywaniem się opowieści i reakcji, który osiąga się, praktykując konkretną partyturę.

To zjawisko dobrze wyjaśnia psychologia poznawcza: doświadczeni tancerze osiągają umiejętność wykonania partytury i rutyny równocześnie poprzez oddelegowanie części zadania pamięci nieświadomej i nawykom. Tkwi w tym jednak pewien paradoks: możliwe, że tancerze w początkowych fazach treningu, zanim jeszcze znakomicie opanują partyturę Hay, mają większą pojemność percepcyjną i generatywną, ponieważ muszą aktywnie kierować swoją uwagą.

Co by było, gdyby taki tancerz miał dostęp do strategii, które w przeciwnym wypadku powstają dopiero na późniejszych etapach uczenia się? Możliwe, że nowicjusz jest w stanie wzbudzić system poprzez 1) szereg ćwiczeń, 2) fazy procesu adaptacji House'a (być może skrócone) z dostępem do treningu koleżeńskiego i 3) właściwości systemu, które zdefiniowała praca House’a. Być może takie podejście z czasem zacznie generować ponadczasowe i ponadindywidualne systemy performatywne. 
Jak wielu artystów, którzy w latach sześćdziesiątych zaczęli rozwijać podejścia improwizacyjne, dzieło Hay zawiera paradoksy. Hay jest mistrzynią i nauczycielką, a jednocześnie celem jej praktyki jest, między innymi, zniesienie hierarchii choreograf-tancerz, co pomaga pozbyć się przywiązania i osiągnąć podwyższony poziom cielesnej percepcji. Ona - mistrzyni - prosi tancerzy, aby podążali za ciałem, a nie za mistrzem, jako nauczycielem. Wydaje się, że jeśli zinterpretujemy zaproszenie do rearanżacji i adaptacji Hay za pomocą House'a i House'a za pomocą Hay poprzez pryzmat teorii systemów dynamicznych DST, odzwierciedla ono ideologię dystansowania się, nieodłączną w pracy Hay. Wspomaga w ten sposób przekazywanie wiedzy i inspiruje nowe kierunki w choreografii.

Przekład: Anna Lewoc

\section{Bibliografia}

Bauer B. (2015), Propensity: Pragmatics and functions of dramaturgy in contemporary dance, [w:] P. Hansen, D. Callison (red.), Dance Dramaturgy: Modes of agency, awareness, and engagement, Palgrave, Basingstoke.

Bleeker M. (2010), What if this were an archive?, „RTRSRCH: Notation”, 2(2).

Bogart A. (2001), Director Prepares: Seven essays on art in theatre, Routledge, London.

Drobnick J. (2006), Deborah Hay: A performance primer, „Performance Research”, 11(2).

Foster S. (2000), Foreword, [w:] D. Hay, My Body, the Buddhist, Wesleyan University Press, Middletown (CT).

Hansen P. (2015a), The dramaturgy of performance generating systems, [w:] P. Hansen, D. Callison (red.), Dance Dramaturgy: Modes of agency, awareness, and engagement, Palgrave, Basingstoke.

Hansen P. (2015b), Email interview with Christopher House (no. 1), 4 April, unpublished.

Hansen P. (2015c), Email interview with Christopher House (no. 2), 8 May, unpublished.

Hansen P., Oxoby R.J. (2017), An Earned Presence: Studying the Effect of Multi-task Improvisation Systems on Cognitive and Learning Capacity, „Connection Science”, 29(1).

Hansen P., House Ch. (2015), Scoring the Generating Principles of Performance Systems, „Performance Research”, 20(6).

Hansen P., Kaeja K., Henderson A. (2014), Self-organization and transition in performance generating systems, „Performance Research”, 19(5).

Hay D. (2000), My Body, the Buddhist, Wesleyan University Press, Middletown (CT).

Hay D. (2007), I'll Crane for You, Solo Score, unpublished.

Hay D. (2013), Performance as Practice, Deborah Hay Dance Company website, http:// dhdcblog.blogspot.ca (dostęp: 14.09.2013).

House Ch. (2006-7), Coaching Notes from Deborah Hay, Solo Performance Commissioning Residence in Findhorn, unpublished.

House Ch. (2015), Notes to Pil Hansen's conference paper The Cognitive Dynamics of Performance Generating Systems ..., 8 May, unpublished. 
Lawlor-Savage L., Goghari M.V. (2016), Dual N-Back Working Memory Training in Healthy Adults: A Randomized Comparison to Processing Speed Training, „PLoS”, 1(11).

Lepecki A. (2010), The body as archive: Will to re-enact and the afterlives of dances, „Dance Research Journal”, 42(2).

Lövdén M., Bäckman L., Lindenberger U., Schaefer S., Schmiedek F. (2010), A theoretical framework for the study of adult cognitive plasticity, „Psychological Bulletin”, nr 136.

Motion Bank (2015), www.motionbank.org (dostęp: 01.06.2015).

Thelen E., Smith L.B. (1994), A Dynamic Systems Approach to the Development of Cognition and Action, MIT Press, Cambridge.

\section{Summary}

How can we archive, pass on, and further develop dance works that are not set, but rather generated systematically on stage? In performance generating systems dancers respond to a specific set of tasks within restrictive rules and while recycling predetermined memories as source materials. To notate these systems we need to grasp and share the principles through which they generate movement interactions and not the composition, which they produce. The question of how these systems work is intrinsically linked to the ways in which they facilitate or inhibit cognitive processes of memory and perception. The systems challenge performers to remain self-aware and pay attention differently while responding to their memories within restraints. Through this process, performers arrive at a differently earned presence that represents a shift in performance epistemology. This shift is, in turn, met by an equally important shift in dramaturgical orientation from what a performance is to how it works and generates. In this chapter, Pil Hansen turns towards Dynamical Systems Theory from the cognitive sciences to develop an accessible and adaptable notation tool that implements these two shifts. Her proposal is advanced through a detailed discussion of how one can notate the choreographer Christopher House's 2015 adaptation of I'll Crane for You, a solo performance commissioning score by Deborah Hay. Hansen's discussion is informed, infused, and complemented by House's responses and reflections upon his practice. Between their two voices, insights into the strategies that dancers devise in response to the cognitive challenges of performance generating systems are discovered as key components of a DSTbased notation tool.

\section{Przypisy}

$1 \quad$ Niniejszy artykul jest rozszerzoną wersją pracy Ocena zasad kreacji systemów performatywnych, opublikowanej przez Hansena i House’a w „Performance Research” w 2015 roku. Rozszerzyliśmy go o pogłębione rozważania na temat wymagań poznawczych i efektów omawianej praktyki. 